\title{
The Impact of Immunization of BCG on Toddler Exposed to Pulmonary TB Patients in Landfill Site of Sukawinatan, Sukajaya Village, Sukarami District Palembang City 2019
}

\author{
$1^{\text {st }}$ A. Kadir, \\ Department of Midwifery \\ Polteknik Kesehatan Kemenkes Palembang \\ Palembang, Indonesia \\ hakadirspdmkes@gmail.com
}

\author{
$2^{\text {nd }}$ Dahliana \\ Department of Midwifery \\ Polteknik Kesehatan Kemenkes Palembang \\ Palembang, Indonesia \\ 69dahlia@gmail.com
}

Corresponding author: hakadirspdmkes@gmail.com

\begin{abstract}
Background Immunization is an effort to prevent disease transmission by administering vaccines. One of the infectious diseases that can be prevented by BCG immunization is pulmonary tuberculosis. Transmission occurs when someone is exposed to pulmonary TB sufferers, especially toddlers. The purpose of this study was to determine the impact of BCG immunization on toddler who were exposed to pulmonary TB patients. The research method was crosssectional with a sample of 60 toddler who were exposed to pulmonary tuberculosis patients in the Sukawinatan area, Sukajaya sub-district, Sukarami district, Palembang city. The results of the study, out of 60 toddlers who were exposed to pulmonary TB there were 4 toddler who were not immunized against BCG and it turned out that 1 of them was infected with pulmonary TB.

It is known from the Chi-square test that there is a significant relationship between BCG immunization status and the incidence of pulmonary tuberculosis in toddler $\alpha 0.001<\rho=0.05$. From the aspect of body weight, toddlers who are infected with pulmonary TB do not gain weight in proportion to age, namely $\rho$ value $=$ $0.003<0.05$ children. Conclusion toddlers who live in the environment of pulmonary TB patients, smokers and in slum areas tend to infected by pulmonary TB.
\end{abstract}

Keywords: BCG immunization, pulmonary tuberculosis.

\section{INTRODUCTION}

Immunization is an effort to prevent death in infants from preventable diseases through vaccines. According to the World Health Organization, 1.5 million children die each year from diseases that can be prevented by immunization [1], [2]. Based on the [3].

diseases that can be prevented by immunization, namely diphtheria with a total of 340 cases, Tetanus Neonatorum 14 cases, pertussis 1,240 cases, and measles with the highest number compared to other diseases, reaching 6,890 cases. Meanwhile, in 2017, the Indonesian Health Center recorded an increase with the number of neonatal tetanus cases reported as many as 25 cases, 14 of which died. So as in cases of measles, which increased more than $2 x$, namely 14,640 cases, with South Sumatra contributing 203 cases. In the city of Palembang, 1 case of diphtheria was recorded in 2017, 1 case of Pertussis, 2 cases of tetanus neonatorum, and 416 cases of measles. Meanwhile, no cases were reported for indications of polio and hepatitis B [3]. In slum areas and poor sanitation environments, there are often many cases of ISPA and pulmonary TB. [3], [4]. Government efforts to implement the Jampersal program (Childbirth Guarantee) have reaped significant results where the Ministry of Health has succeeded in protecting babies from diseases that can be prevented by immunization 
(PD3I) for two rolling year [3], [5]. For Complete Basic Immunization (IDL) in 2015, covering 4,139,903 babies, then in 2016 it increased to $4,361,072$ babies [2]. Meanwhile, the achievements in 2017 were $4,299,095$ babies, with a percentage of $90.8 \%$ [2]. In South Sumatra Province, the coverage of Complete Basic Immunization in infants in 2017 showed a figure of 151,642 babies $(95.3 \%)$ and Palembang City as many as 25,736 babies from the target number of 26,941 babies or around $95.53 \%$ [3]. This means there are still around 1205 babies in Palembang City who do not receive complete basic immunization [3]. Meanwhile, the immunization dropout rate is still experiencing up and down, based on data from the Directorate General of Prevention and Disease Control, the dropout rate DPT / HB (1)-measles immunization from 2015 is 2.9. In 2016 it decreased to 2.4. However, in 2017 there was an increase of 2.6 with South Sumatra province contributing of 0.3 [3]. This immunization drop out can result in the effectiveness of the vaccine being not optimal in protecting children from disease [6], [7]. Pulmonary tuberculosis can be contagious, transmission can be prevent by immunization, and pulmonary $\mathrm{TB}$ found in areas with poor hygiene and sanitation [1], [8]. Sukawinatan is a landfill where many people with pulmonary TB.

Based on the data and description above, the researcher intends to research with the title "Impact of Immunization of BCG on Toddler Exposed to Pulmonary TB Patients in Landfill site Of Sukawinatan Kelurahan Sukajaya Kecamatan Sukarami, Palembang City 2019. Research Problems namely "Is there an impact of BCG immunization on toddlers exposed to pulmonary TB patient in the landfill area of sukawinatan of kelurahan Sukajaya, kecamatan Sukarami, Palembang city in 2019". General Purpose to determine the impact of impact of BCG immunization on toddlers exposed to pulmonary $\mathrm{TB}$ patient in the landfill area of sukawinatan, kelurahan Sukajaya, kecamatan Sukarami, Palembang city in 2019. Benefits of Research. We hoped that it can provide basic information and data for research in improving the health status of mothers and children and for pulmonary TB patients in avoiding disease transmission and understanding pulmonary TB disease and immunization and diseases that can be prevented by immunization and also reducing immunization drop out rates.

\section{METHOD}

This research was conducted in the landfill of sukawinatan, kelurahan Sukajaya, kecamatan
Sukarami, Palembang City 2019 from May 2019 to August 2019. This research method is a cross- sectional study with case control with matching age and sex with variables toddler exposed to pulmonary tuberculosis patients and the impact of BCG immunization.

The population in this study were all Toddler in the area of the Sukawinatan landfill, kelurahan Sukajaya, kecamatan Sukarami, Palembang City in 2019.

The sample in this study were children under five who were exposed to pulmonary tuberculosis patients in the area of the Sukawinatan landfill, kelurahan Sukajaya, kecamatan Sukarami, Palembang City. The criteria referred to are as follows:

a) Children aged 1 - 5 years are in the Sukawinatan landfill area

b) Live with people with pulmonary tuberculosis

c) Willing to be involved in this research

The attitude of the respondent has the autonomous right to make a conscious decision to participate or not in a research. Before conducting the research, the researcher gave an explanation to the respondent about the purpose and purpose of the research to be carried out and the respondent was given a statement letter which agreed to participate in this research

\section{RESULTS}

This Univariate Analysis to determine the frequency distribution and proportion of the independent variables, namely BCG immunization and weight of children under five and the dependent variable, namely children exposed to pulmonary tuberculosis. Distribution data displayed in tabular and text form. The sample of this study amounted to 60 people. From the results of research conducted on 60 samples, the status of BCG immunization is 56 people $(71.670 \%)$ greater than the children who did not immunize 4 BCG $(8.33 \%)$. From the results of research conducted on 60 toddlers, body weight was grouped into 2 categories, namely normal weight and abnormal body weight under five who had normal weight, namely 56 people (93.33\%), greater than 4 people with abnormal body weight (6.67). \%).

It known that toddlers, who have pulmonary tuberculosis is 1 person $(3.33 \%)$, are smaller than those who do not have pulmonary TB by 59 people $(96.67 \%)$. 
Table 1. Distribution of toddlers who do not receive BCG immunization

\begin{tabular}{cccccc}
\hline No. & Age & L & P & amount & \% \\
\hline 1. & $0-3$ years & 1 & 2 & 3 & 60 \\
\hline 2. & $3-5$ years & 0 & 1 & 1 & 40 \\
\hline & & & & & \\
\hline
\end{tabular}

\section{Relationship between BCG Immunization Status and Incidence of Pulmonary TB in Toddlers}

This research was conducted on 60 toddlers where the BCG immunization status was divided into 2 categories, namely BCG immunization (Yes) and No BCG immunization (No), while the incidence of pulmonary TB in children under five was divided into 2 categories namely yes (if pulmonary TB) and no (if not Pulmonary TB).

Based on the results of the chi-square test, it showed that there was a significant relationship between BCG immunization status and the incidence of pulmonary TB in children under five $p$ value $0.001<\square=0.05$. This means that there is a relationship between immunization status and the incidence of pulmonary TB in children under five in the Palembang City Final Disposal Site (TPA) in 2019

Table 2. Relationship of Weight and Incidence of Pulmonary

\begin{tabular}{|c|c|c|c|c|c|c|c|}
\hline \multirow{3}{*}{ Weight } & \multicolumn{4}{|c|}{ Pulmonary TB incidence } & \multirow{2}{*}{\multicolumn{2}{|c|}{ Total }} & \multirow{3}{*}{$P$ value } \\
\hline & \multicolumn{2}{|c|}{ Yes } & \multicolumn{2}{|c|}{ Not } & & & \\
\hline & $\mathbf{n}$ & $\%$ & $\mathbf{N}$ & $\%$ & $\mathbf{N}$ & $\%$ & \\
\hline Normal & 0 & 0 & 57 & 100 & 57 & 100 & \\
\hline $\begin{array}{l}\text { Abnorm } \\
\text { al }\end{array}$ & 1 & 50 & 2 & 50 & 3 & 100 & 0.03 \\
\hline amount & 1 & 3.33 & 59 & 96.67 & 60 & 100 & \\
\hline
\end{tabular}

This research was conducted on 60 respondents in which parity was divided into 2 categories, namely normal weight (if the body weight is according to the KMS chart) and abnormal (if the body weight is not according to KMS), while the incidence of pulmonary tuberculosis in toddlers is divided into pulmonary tuberculosis and not affected. Pulmonary TB
Table 3. Relationship of Weight and Incidence of Pulmonar

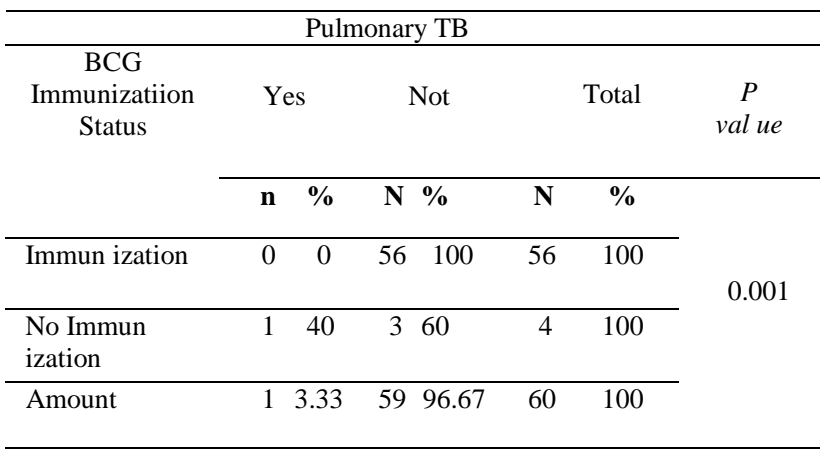

Table 4. Weight Frequency Distribution

\begin{tabular}{cccc}
\hline Age & amount & $\begin{array}{c}\text { Average } \\
\text { weight }\end{array}$ & $\%$ \\
\hline $0-1$ years & 7 & $7 \mathrm{~kg}$ & 11.7 \\
\hline$>1-2$ years & 4 & $9 \mathrm{~kg}$ & 6.7 \\
\hline$>2-3$ years & 7 & $10 \mathrm{~kg}$ & 10 \\
\hline$>3-4$ years & 25 & $14.1 \mathrm{~kg}$ & 41.7 \\
\hline$>4-5$ years & 7 & $20.4 \mathrm{~kg}$ & 26.6 \\
\hline Amount & 60 & & 100 \\
\hline
\end{tabular}

Table 5. Distribution of Toddler environmental

\begin{tabular}{lcc}
\hline $\begin{array}{c}\text { Smoker } \\
\text { environment }\end{array}$ & amount & $\%$ \\
\hline Passivesmokers & 58 & 96.5 \\
\hline Do not smoke & 2 & 3.5 \\
\hline Amoumt & 60 & 100 \\
\hline
\end{tabular}

Table 6. Distribution of Toddler residence

\begin{tabular}{lcc}
\hline Residence & Amount & $\%$ \\
\hline Not seedy & 5 & 8.3 \\
\hline Slum & 10 & 16.7 \\
\hline Very rundown & 45 & 75 \\
\hline amount & 60 & 100 \\
\hline
\end{tabular}

Bivariate Analysis was conducted to determine the relationship between the independent variable (immunization status) and the dependent variable (pulmonary tuberculosis) in the landfill of Sukawinatan, Sukajaya Sukarami, Palembang. This study will look at the relationship between the independent variable and the dependent variable with a significance limit of $\alpha 0.05$, meaning that if the $p$ value $<0.05$, the relationship will be significant (significant) 
and if the $\mathrm{p}$ value $>0.05$, the relationship is not significant. The statistical test used is the Chi-Square test, which tests the relationship of the variables.

The results of this study indicate that there are 56 immunized children and four children who did not receive immunization, all of them lived in the environment with pulmonary TB patients. Chi-square test analysis showed that there was a significant relationship between BCG immunization status and the incidence of pulmonary TB. The results of this study are in accordance with the research of Dr. Hardiati SP.A. Regarding the immune use of the BCG Vaccine for the prevention of transmission of tuberculosis. Children under five who are immunized with BCG get better immunity so that they are less likely to infected by TB disease compared to children under five who do not receive $\mathrm{BCG}$ immunization

From this study, it was found that 1 child was infected with pulmonary tuberculosis and whose weight was not normal according to KMS standards (Kartu Menuju Sehat)

Chi-square test results. This study shows that children under five who infected with pulmonary TB have a body weight that does not increase and even tends to decrease with age

The results of this study also illustrate that the children under five in the Sukawinatan area live in a very slum area with 45 children, while the other 10 children live in the slum area and 5 children live in not a slum area. Thus his life in a situation that is prone to contracting infectious diseases

The data obtained from this study showed that as many as 59 children were significant smokers in the family environment it means those children tend to infected by pulmonary TB infection. This study found that there were 43 children living in a pulmonary TB environment aged $>3-5$ years.

Univariate analysis illustrates that children living in the Sukawinatan area, kelurahan Sukajaya, kecamatan Sukarami , Palembang are at high risk for contracting pulmonary $\mathrm{TB}$ and other respiratory infections considering they live in a slum environment, smoking families and are exposed to pulmonary TB sufferers from adults.

\section{CONCLUSION}

The number of toddlers infected with pulmonary tuberculosis in the Sukawinatan landfill area was 60 out of 1 positive person for pulmonary TB out of 59 not affected by pulmonary TB in 2019. The number of toddlers exposed to pulmonary tuberculosis in sukawinatan were 4 people who not immunized and 56 people who immunized in the sukawinatan area. Of the 60 children who are exposed to pulmonary TB, it turns out that the impact that has happened to children who are not immunized is 5 people who have pulmonary TB as many as 1 person.

\section{SUGGESTION}

It is suggested that this writing be continued with due observance of the nutritional state of pulmonary tuberculosis patients.

\section{REFERENCES}

[1] Bomboa V, Pascoal M, Lumy F. Pengaruh Penyuluhan Imunisasi Campak Terhadap Peningkatan Pengetahuan Dan Sikap Ibu. Jurnal Ilmiah Bidan 2015;3:45-50.

[2] Indonesian Pediatric Society. Seputar Pekan Imunisasi Dunia. Jakarta: 2018.

[3] PUSDATIN KEMKES. Data dan Informasi Profil Kesehatan Indonesia 2017. Jakarta: Kementerian Kesehatan Republik Indonesia; 2018.

[4] Makamban Y, Salmah U. Faktor yang Berhubungan dengan Cakupan Imunisasi Dasar Lengkap Pada Bayi di Wilayah Kerja Puskesmas Antara Kota Makassar 2014.

[5] Menkes RI. Peraturan Menteri Kesehatan Republik Indonesia Nomor 12 Tahun 2017 Tentang Penyelenggaraan Imunisasi. Indonesia: 2017.

[6] Kinanti AA. Dokter: Drop Out Imunisasi, Efektivitasnya Bisa Turun. DetikHealth 2017.

[7] Nutriclub. Imunisasi untuk Anak Berusia 0-2 Tahun. Jakarta: 2017.

[8] Harlimton CK. Gambaran Tingkat Pengetahuan dan Kesadaran Ibu Mengenai Pentingnya Imunisasi Dasar Lengkap pada Anak Di Puskesmas Kassi-Kassi. Fakultas Kedokteran, Universitas Hassanudin, Makassar, 2017. 